\title{
М.В. ЖижинА*
}

\section{ИННОВАЦИОННОЕ РАЗВИТИЕ КРИМИНАЛИСТИКИ НА СОВРЕМЕННОМ ЭТАПЕ}

Ключевые слова: инновации, развитие криминалистики, современные тенденщии, технологии, криминалистика

Вряд ли кто-нибудь в современной России возьмет на себя смелость отрицать актуальность темы инноваций. И речь идет не только об экономической сфере, но и обо всех иных сферах общественных отношений: науке, образовании, медицине, юриспруденции и т.д. В подтверждение этой мысли сошлемся на Стратегию национальной безопасности Российской Федерации до 2020 г., в которой становление и развитие национальной инновационной системы развития общества объявлено приоритетной задачей для нашей страны ${ }^{1}$.

Определение термина «инновация» безусловно обладает экономико-технологическими аспектами. В словарях технической направленности «инновация» (нововведение) трактуется как результат творческой деятельности, направленной на разработку, создание и распространение новых видов изделий, технологий, внедрение новых организационных форм и

(C) Жижина М.В., 2012

* Кандидат юридических наук, доцент кафедры криминалистики Московской государственной юридической академии имени О.Е. Кутафина. [mzhizhina@ yandex.ru]

${ }^{1}$ СПС «КонсультантПлюс». 
т.д. ${ }^{2}$ Однако его современное звучание значительно обогатилось: создаются «инновационные образовательные программы», проводится «инновационная внешняя политика», принимаются «инновационные решения» и т.п. В широком смысле «инновация» - использование в той или иной сфере общества результатов интеллектуальной (научно-технической) деятельности, направленных на совершенствование процесса деятельности или его результатов.

Применительно к криминалистике термин «инновация»- не просто игра слов или использование модного термина.

Одной из основных задач науки криминалистики является создание и применение соответствующих средств, приемов и методов раскрытия и расследования преступлений, установления истинных обстоятельств дела. Для того чтобы быть адекватной современным угрозам, криминалистика интегрирует и синтезирует в себе последние достижения науки и техники. Сегодня в своих целях она осуществляет активнейшую «инновационную» деятельность: успешно разрабатывает, внедряет и использует новейшие информационные и наукоемкие технологии, различного рода интеллектуальные системы, нанотехнологии и др.

Чтобы осмыслить инновационный характер развития криминалистики на современном этапе, необходимо обратиться к рассмотрению одного из ее законов - ускорению темпов развития криминалистики под влиянием научно-технического прогресса ${ }^{3}$.

Как известно, научно-технический прогресс является одним из основных факторов, обусловивших в свое время возникновение криминалистики как науки и ее дальнейшее активное развитие. Именно быстрый научно-технический и бурный промышленный рост, положивший начало профессиональной, а в дальнейшем - организованной преступности, послужил толчком для создания отрасли знания - криминалистики, способной противостоять преступности нового качества ${ }^{4}$.

Осознанная обществом необходимость научного обоснования системы мер по раскрытию и расследованию преступлений, их наработки и практической реализации всегда была и остается зависимой от достижений научно-технического прогресса. Без их учета, как указывал А.И. Винберг, «невозможно было бы правильно понять сущность криминалистики, служебной ролью которой является внедрение в уголовное судопроизводство

${ }^{2}$ См.: Ткачев В.Н. К вопросу о нормативно-правовом регулировании инновационной деятельности в Российской Федерации // Законодательство. 2011. № 5. C. 30 .

${ }^{3}$ См.: Аверьянова Т.В., Белкин Р.С., Корухов Ю.Г., Россинская Е.Р. Криминалистика: учебник / под ред. Р.С. Белкина. М., 1999. С. 61.

${ }^{4}$ См.: Криминалистика: учебник / под ред. Е.П. Ищенко. М., 2011. С. 9. 
современных возможностей науки и техники для задач раскрытия и расследования преступлений» 5 .

Тенденциям и перспективам развития отечественной криминалистики под влиянием научно-технического прогресса много внимания уделено в работах Р.С. Белкина, который в качестве проявлений следствий научно-технического прогресса выделял ускорение темпов развития науки криминалистики, вызванное возрастающим объемом фундаментальных и прикладных исследований, ускоренным развитием тех отраслей знаний, данные которых используются в криминалистике ${ }^{6}$.

Как известно, криминалистика единственная из всех юридических дисциплин теснейшим образом связана с естественными и техническими науками, достижения которых генерируются в криминалистике и вместе с тем выступают главным источником и средством развития криминалистической техники как раздела науки криминалистики. Именно естественные и технические науки всегда были приоритетным направлением для нашей страны. В том числе и этим объясняется то обстоятельство, что по разработке технико-криминалистических средств, методов и методик, используемых, например, в экспертных исследованиях, советские криминалисты в 1960-1980-х гг. занимали одно из лидирующих мест в мире, успешно справляясь со стоявшими перед ними задачами по борьбе с преступностью.

На сегодняшний день в современной России противоречия процесса формирования новых социально-экономических рыночных отношений вкупе с новым витком мирового научно-технического прогресса привели к росту количественных и качественных показателей преступности, а также негативных тенденций в ее динамике и структуре: профессионализации, интеллектуализации, объединению антиобщественных сил в преступные группы и сообщества, появлению новых видов преступлений и т.д. Все это поставило перед отечественной криминалистикой настоятельный социальный заказ на поиск адекватных криминальной ситуации средств, приемов и методов, позволивших бы обуздать «взбесившуюся» преступность ${ }^{7}$.

Однако научно-технический прогресс, порождая противоречия, предоставляет и возможность для их решения - в непосредственной взаимосвязи с достижениями науки и техники. Как точно подметил А.Ф. Волынский, «преступников, которые летают на самолетах, можно обогнать только с помощью электроники. Их изобретательности, умноженной на современные технические возможности, необходимо объективно противостоять, опережая развитие современных научно-технических средств и ме-

${ }^{5}$ Винберг А.И. Техника и уголовное судопроизводство // Советское государство и право. 1970. № 7. С. 9. 152.

${ }^{6}$ См.: Белкин Р.С. Курс криминалистики. 3-е изд., доп. М., 2001. С. 95

${ }^{7}$ См. подробнее: Алексеев А.И., Овчинский В.С., Побегайло Э.Ф. Росийская уголовная политика: преодоление кризиса. М., 2006. С. 6-59. 
тодов». Только таким путем необходимо действовать в целях обеспечения безопасности государства, общества, каждого человека.

Преодолевая последствия серьезного экономического спада переходного периода, современная политика нашего государства направляет усилия на аккумуляцию самых передовых достижений естественных наук, стимулирование развития фундаментальных, поисковых и прикладных исследований, создание высокотехнологичного сектора экономики, обновление и модернизацию производства. Соответствующим образом это отражается на состоянии и развитии криминалистики. Интегрируя новейшие достижения науки и техники, криминалистика создает для правоохранительных органов соответствующие современным угрозам инновационные средства, приемы и методы борьбы с преступностью.

На наш взгляд, можно выделить три основных направления инновационного развития криминалистики на современном этапе:

Во-первых, использование принципиально новых материалов, разработка и внедрение новых технологий и решений.

Данная тенденция характерна, в основном, для развития криминалистических экспертных исследований. Так, например, отечественные эксперты-криминалисты достигли значительных успехов в исследовании различных объектов биологического, синтетического и иного происхождения. В последние десятилетия в экспертной практике все шире стали использоваться атомно-абсорбционный анализ, лазерный микроанализ и другие наукоемкие высокоточные методы ${ }^{8}$. Более того, в практику производства экспертиз внедряются нанотехнологии.

Нанотехнологии провозглашены фундаментом научно-технической революции в XXI в., одним из наиболее перспективных и востребованных направлений науки, технологий и промышленности, а формирование национальной наноиндустрии объявлено важнейшим приоритетным стратегическим направлением для страны.

С использованием нанотехнологии открываются принципиально новые возможности и для решения экспертных задач. Так, например, для нужд криминалистики было адаптировано физико-аналитическое оборудование, созданное на предприятиях отечественного ВПК для развития космической микроэлектроники, - спектрометры для особо точного анализа поверхности и объема твердых тел методами ионной, электронной и фотонной спектроскопии 9 .

${ }^{8}$ См.: Ищенко Е.П. Тенденции и перспективы развития криминалистики в свете научно-технического прогресса // Актуальные проблемы разработки и внедрения в практику борьбы с преступностью криминалистических средств и методов: мат. 4-го и 5-го науч.-практич. криминалистических семинаров. М., 2006.

${ }^{9}$ См.: Плоткин Д.М., Ищенко Е.П. Новейшие методы исследования вещественных доказательств в криминалистике: науч.-практич. поС. Рязань, 2005. 
Данные спектрометры отличаются ничтожностью анализируемого участка, способны уловить толщину анализируемого слоя до 1 атома с выявлением всех видов атомов в объекте с неизвестным составом. Анализ производится последовательным удалением с поверхности материала атомных слоев с обнажением следующих. Как образно определяет данную методику Е.П. Ищенко, «если до последнего времени “книгу” поверхностных наслоений читали, перелистывая сразу по 3000 страниц, то теперь можно прочитать каждую страницу и подсчитать на ней все группы букватомов» ${ }^{10}$. Соответственно, объем доказательственной информации многократно увеличивается. Кроме того, для обеспечения наглядности и убедительности произведенного экспертного исследования по результатам анализа можно построить трехмерную картину распределения атомов нужного типа.

Для использования данного оборудования в криминалистических целях были разработаны методики подготовки образцов и производства исследований, обеспечивающие надежное сохранение исходной информации о следах, а также других индивидуальных особенностях исследуемых объектов. Как указывают авторы, с их помощью был проведен ряд криминалистических экспертиз по нескольким десяткам уголовных дел ${ }^{11}$. Таким образом, были решены различные криминалистические задачи, ранее считавшиеся неразрешимыми ввиду отсутствия аппаратуры и методик ее применения в экспертной практике.

Другим примером использования нанотехнологий в криминалистических целях является разработка новых методов, расширяющих возможности идентификации человека при проведении генотипоскопической экспертизы. Разработка биочипа, позволяющего установить личность субъекта по ничтожно малым следовым количествам ДНК с вероятностью 99,6 \%, позволяет сегодня проводить идентификацию лиц при обнаружении на месте происшествия, скажем, смятой в руке салфетки или окурка сигареты с малым количеством слюны, что было невозможно ранее ${ }^{12}$.

Таким образом, эксперты-криминалисты создают теоретический фундамент для перспективной разработки, внедрения и использования «инновационных продуктов» - различных методик по использованию нанотехнологий при расследовании преступлений.

Следующее направление инновационного развития криминалистики можно проследить в связи с внедрением различного рода инновационных технологий в производство следственных действий.

${ }^{10}$ Ищенко Е.П. О внедрении нанотехнологий в криминалистику и судебную экспертизу // Стратегия отправления правосудия по уголовным делам в современной России как социальное взаимодействие личности и государства: сб. науч. ст. В 2 ч. Ч. 1. Курск, 2009. С. 203.

${ }^{11}$ См.: Плоткин Д.М., Ищенко Е.П. Указ. соч. С. 76.

${ }^{12}$ См.: Молекулярная биология. 2010. Т. 44. № 3. 
Научно-техническая составляющая современных криминалистических технологий особенно активно реализуется при проведении осмотров. В деятельность органов досудебного следствия внедрены комбинированные комплекты научно-технических средств: унифицированный комплект следователя; комплект поисковых средств следователя (набор «Поиск»); комплект научно-технических средств для осмотра места пожара (набор «Пожар»); комплект научно-технических средств для осмотра взрывных устройств и места взрыва; комплект научно-технических средств для работы с микрообъектами (набор «Микро» или «Молекула»); разработанный ЭКЦ МВД по Республике Татарстан и КГТУ им. А.Н. Туполева прибор «ПОС-Т1», крайне необходимый для обнаружения и изъятия пылевых следов обуви с ковра, ткани, линолеума, дерева, кожи и т.д. ${ }^{13}$

Использование тепловизоров при проведении осмотров места происшествия и обысков (например, ThermaCAM - компактная полнофункциональная инфракрасная камера ${ }^{14}$ ) позволяет производить поиск потерпевших, следов их пребывания на обширных территориях по остаточным термическим свойствам и т.д. Широкое применение получили комплекты изъятия запаховых следов, представляющие собой наборы герметично укупоренных сосудов, микронасосов, абсорбирующих материалов и т.д. ${ }^{15}$

Третье направление инновационного развития современной криминалистики связано с активным внедрением информационных технологий в деятельность правоохранительных органов.

Проблема информатизации и алгоритмизации деятельности следователя стоит остро уже давно ${ }^{16}$. Криминалистические технологии при осмотрах мест происшествий - это непрерывный процесс использования комплекса современных научно-технических средств и методов, тактикокриминалистических приемов в условиях дефицита времени, необходимости решения значительного количества сложных мыслительных задач при крайней недостаточности информации о событии преступления. Поэтому ведется разработка и оснащение следователя новейшими информационны-

${ }^{13}$ См.: Шепитько В.Ю. Инновации в криминалистике и следственной деятельности // Проблемы управления органами расследования преступления в связи с изменениями уголовно-процессуального законодательства: мат. межвуз. науч.практич. конф. В 2 ч. Ч. II. М., 2007. С. 46.

${ }^{14}$ См.: Хижняк Д.С. Осмотр места происшествия: учеб. поС. М., 2007. C. 32 .

${ }^{15}$ См.: Шамонова Т.Н. Осмотр места обнаружения признаков убийства: учеб. поС. М., 2008. С. 32-34.

${ }^{16}$ См.: Ищенко Е.П. Алгоритмизация следственной деятельности: Методологические основы // Актуальные проблемы следственной деятельности: межвуз. сб. науч. тр. Свердловск, 1990; Ищенко Е.П., Сливинский К.О. Алгоритмизация следственных действий: общий подход// Академический юридический журнал. 2002. № 4 (10); Ищенко Е.П., Семьина Н.Б. Алгоритмизация следственной деятельности. М., 2010; и др. 
ми технологиями (включая АРМ следователя; компьютерные комплексы получения криминалистически значимой информации; оснащение следователя локальной и периферической сетями со всеми участниками процесса расследования с использованием возможностей Единой телекоммуникационной системы - ЕИТКС и т.д. $)^{17}$.

В экспертной же практике достаточно давно применяются количественные автоматизированные математико-кибернетические методы и методики. Они направлены на преодоление субъективизма, на повышение достоверности экспертных выводов независимо от индивидуальных особенностей познающего субъекта. Например, в судебном почерковедении количественные автоматизированные методы разработаны, внедрены в практику и успешно применяются при проведении экспертных исследований для решения различных задач применительно практически к каждому почерковому объекту ${ }^{18}$.

Однако принципиально иные возможности открывает использование «интеллектуальной системы». В ее основу положен логикокомбинаторный ДСМ-метод автоматического порождения гипотез, который осуществляет интеллектуальный анализ введенных данных и самостоятельно производит решение задачи ${ }^{19}$. Апробация данной методики показала весьма высокие результаты при установлении исполнителя рукописи, его пола и возраста.

Разработка и использование в практике производства не только почерковедческой, но и любой иной экспертизы таких «интеллектуальных систем» позволит устранить субъективизм экспертной оценки, что повысит достоверность экспертного заключения как источника доказательств по делу и будет в целом способствовать решению основных задач судопроизводства.

${ }^{17}$ См.: Аминев Ф.Г. Об использовании криминалистических технологий при осмотре места происшествия // Российский следователь. 2009. № 20 // СПС «КонсультантПлюс».

18 См., например: Смирнов А.В. Программа «ОКО-1» для исследования кратких и простых почерковых объектов // Теория и практика судебной экспертизы. Вып. 1. М., 2006.; Сидельникова Л.В., Герасимов А.Н. Комплексная методика установления возраста и психологических свойств исполнителя текста, выполненного почерком высокой и выше средней степени выработанности. М., 2005; Ли Л.Е., Смирнов А.В. Количественные методы и автоматизация в судебном почерковедении // Проблемы автоматизации, создания информационно-поисковых систем и применения математических методов в судебной экспертизе. М., 1987.

${ }^{19}$ См.: Гусакова С.М., Комаров А.С. Интеллектуальная система для решения идентификационной задачи в почерковедении // Искусственный интеллект и принятие решений. 2010. Вып. 4; Устинов В.В. Модельные методы судебнопочерковедческого исследования: проблемы и тенденции развития: дис. ... канд. юрид. наук. М., 2011. 
Выделенные нами направления инновационного развития ни в коей мере не исчерпывают возможности применения инновационных технологий в криминалистике. Разработка и внедрение криминалистических инновационных продуктов ведется и по иным направлениям криминалистического обеспечения предварительного расследования и судопроизводства.

Перечисление созданных принципиально новых или усовершенствованных средств, приемов, методов и методик - «инновационных продуктов», применяемых в криминалистике, разработанных и внедренных в практику за всю историю ее развития, составит многотомное издание. Более того, благодаря мощному влиянию научно-технического прогресса все поступательное развитие криминалистики представляет собой инновационную деятельность по созданию различного рода «инновационных продуктов».

Современное состояние инновационной деятельности в криминалистике прекрасно иллюстрирует проводящаяся ежегодно международная выставка средств обеспечения безопасности государства «Интерполитекс», которая демонстрирует все многообразие современных криминалистических средств, обеспечивающих проведение следственных действий и безопасность сотрудников правоохранительных органов.

Необходимо отметить, что применение криминалистических инновационных продуктов должно отвечать ряду условий.

Допустимость использования является основополагающим принципом применения всех криминалистических разработок в судопроизводстве. Использование инновационного продукта допустимо, если при этом не нарушаются права и законные интересы граждан, нравственные, этические нормы.

Далее. При применении необходимо обеспечить сохранность источников доказательственной информации: следов и предметов - вещественных доказательств, а также отсутствие искажений фиксируемой либо анализируемой информации.

Следующим обязательным условием является обеспечение гарантий научной состоятельности и надежности криминалистических инновационных продуктов, т.е. сам продукт и правила его применения должны базироваться на строго научных данных, пройти апробацию, в необходимых случаях - сертификацию и быть рекомендованными к практическому использованию.

Квалифицированное применение криминалистических инновационных продуктов должно осуществляться соответствующими специальными субъектами (следователем (дознавателем), судьей, специалистом, экспертом, оперативными сотрудниками). Это обязывает последних в совершенстве знать и правильно использовать данные криминалистические инновационные продукты, обеспечивая при этом объективность и всесторонность профессиональной деятельности по раскрытию и расследованию преступлений. 
К обязательным условиям относятся безопасность использования и эффективность применения.

В связи с тем, что сфера применения криминалистических инновационных продуктов - это деятельность правоохранительных органов на предварительном и судебном следствии, необходимым является обязательное отражение условий, порядка и результатов применения в процессуальных документах (в протоколах следственных (судебных) действий, заключениях экспертов и др.). Этим удостоверяется сам факт использования данных продуктов, обеспечивается оценка полученной с их помощью доказательственной информации, создаются условия для ее всесторонней проверки.

Мы полагаем, что создание и внедрение криминалистических инновационных продуктов следует объявить одной из приоритетных задач криминалистики на современном этапе. В связи этим определенного пересмотра требуют и отдельные науковедческие положения.

Разработка данной тематики представляется нам весьма актуальной и значимой как в теоретическом, так и практическом аспекте, так как только через криминалистику правоприменительная деятельность может быть насыщена инновационными продуктами и технологиями. В связи с изложенным, престиж и значение криминалистики в ряду базовых юридических дисциплин на современном этапе должны неуклонно повышаться.

Материал поступил в редакиџю 17.11.11. 